\title{
How does a neuron "know" to modulate its epigenetic machinery in response to early-life environment/ experience?
}

\author{
Carley A. Karsten ${ }^{1,2}$ and Tallie Z. Baram ${ }^{1,2}$ * \\ 1 Department of Anatomy and Neurobiology, University of California-Irvine, Irvine, CA, USA \\ 2 Department of Pediatrics, University of California-Irvine, Irvine, CA, USA
}

Edited by:

Tania L. Roth, University of Delaware, USA

\section{Reviewed by:}

Dominique Walker, Douglas Hospital

Research Center, Canada

Elif Aysimi Duman, Bogazici

University, Turkey

\section{*Correspondence:}

Tallie Z. Baram, Department of Anatomy and Neurobiology,

University of California-Irvine, B150

Medical Sciences I, ZOT 4475, Irvine,

CA 92697-4475, USA

e-mail: tallie@uci.edu
Exciting information is emerging about epigenetic mechanisms and their role in long-lasting changes of neuronal gene expression. Whereas these mechanisms are active throughout life, recent findings point to a critical window of early postnatal development during which neuronal gene expression may be persistently "re-programed" via epigenetic modifications. However, it remains unclear how the epigenetic machinery is modulated. Here we focus on an important example of early-life programing: the effect of sensory input from the mother on expression patterns of key stress-related genes in the developing brain. We focus on the lasting effects of this early-life experience on corticotropin-releasing hormone $(\mathrm{CRH})$ gene expression in the hypothalamus, and describe recent work that integrates organism-wide signals with cellular signals that in turn impact epigenetic regulation. We describe the operational brain networks that convey sensory input to $\mathrm{CRH}$-expressing cells, and highlight the resulting "re-wiring" of synaptic connectivity to these neurons. We then move from intercellular to intracellular mechanisms, speculating about the induction, and maintenance of lifelong $\mathrm{CRH}$ repression provoked by early-life experience. Elucidating such pathways is critical for understanding the enduring links between experience and gene expression. In the context of responses to stress, such mechanisms should contribute to vulnerability or resilience to post-traumatic stress disorder (PTSD) and other stress-related disorders.

Keywords: synapses, corticotropin-releasing hormone, CRF, glutamate, hypothalamus, epigenetics, stress, maternal care

\section{INTRODUCTION}

Neuronal gene expression is amenable to re-programing by environment and experience (1-3). The neuroendocrine stress axis is influenced by environment and experience during early postnatal development, and these changes endure. For example, maternalderived sensory input is critical for setting the tone of the hypothalamus-pituitary-adrenal (HPA) axis for life via changes in the expression of glucocorticoid receptor (GR) in the hippocampus and of hypothalamic corticotropin-releasing hormone $(\mathrm{CRH})$. High levels, or predictable bouts, of maternal-derived sensory stimulation result in an attenuated stress response and resilience to stress $(4,5)$. In contrast, early-life stress causes adults to exhibit augmented stress responses and cognitive impairments, associated with changes in expression of CRH and GR (6-8). Recently, it has been proposed that it is the patterns of maternal care that contribute crucially to the perception of stress early in life, and to the subsequent modulation of brain function. Thus, chaotic, fragmented sensory inputs from the mother influence neuronal networks involved in stress for the life of the animal in a direction opposite to that of predictable and consistent patterns (9). Thus, an important common basis may exist for both the beneficial and the adverse consequences of early-life experiences: the pattern of sensory input onto the developing brain might constitute an important parameter that influences the function of stress-sensitive neurons throughout life.

It is suspected that the endurance of the effects of sensory input during this critical period derives from activation of epigenetic mechanisms leading to changes in gene expression that are maintained throughout the lifetime. Here we review the neuroanatomical and molecular pathways bridging sensory input on a whole-brain scale with gene expression programing after distinct early-life experiences. We discuss the implications of these processes to post-traumatic stress disorder (PTSD).

\section{EPIGENETICS AND EARLY-LIFE EXPERIENCE}

The nature of epigenetic mechanisms is amply discussed throughout this collection of papers, and will not be described in detail here. Epigenetics offers an enticing explanation for how relatively brief sensory experiences may lead to long-lasting changes in neuronal function. Indeed, changes in components of chromatin, including DNA methylation or histone modifications have been examined after early-life experience, and found in several key genes involved in regulation of the HPA axis [GR, (10); CRH, (11); arginine vasopressin, (12)]. Here we focus on the lasting repression of $\mathrm{CRH}$ in hypothalamic neurons that results from positive maternal care early in life (13). This finding has 
been confirmed by numerous subsequent studies $(4,5)$. We focus on the $\mathrm{CRH}$ gene both as an important regulator of the stress response (14) and as a likely contributor to the phenotype engendered by nurturing early-life maternal signals, because modulation of $\mathrm{CRH}$ function through blocking of $\mathrm{CRH}$ receptor type 1 recapitulated the effects of augmented maternal care in non-nurtured pups (15). A second reason for a focus on the CRH gene is its use as a "marker" gene: the reliable detection of $\mathrm{CRH}$ repression after augmented maternal care suggests that understanding the mechanism that represses $\mathrm{CRH}$ expression enduringly might provide a key to understanding general processes that influence expression programs involving numerous other genes as well. Finally, in the context of the current review, a significant body of literature has implicated aberrant expression and central (CSF) release of CRH in the pathophysiology of PTSD (16-19).

\section{HOW DOES A CRH-EXPRESSING NEURON KNOW TO MODULATE CRH GENE EXPRESSION?}

Corticotropin-releasing hormone gene expression is regulated by transcription factors, and these in turn are activated by signals that reach the nucleus from the membrane, and often involve calcium signaling (20). Synaptic input onto the CRH-expressing neuron includes a number of neurotransmitters, of which glutamate constitutes a major excitatory input (21). Indeed, glutamatergic signaling in the PVN is necessary for the initiation of the endocrine stress response, and glutamate receptor agonists delivered to the PVN drive CRH release $(22,23)$. Recent research has revealed that early-life augmented care leads to a transient reduction in the number and function of glutamatergic synapses to CRH neurons in the PVN (11). Using several methods (immunohistochemistry, electron microscopy, and electrophysiology), Korosi et al. discovered that (1) the number of glutamatergic terminals abutting $\mathrm{CRH}$-positive neurons was reduced, (2) the number of asymmetric, putative excitatory terminal boutons onto $\mathrm{CRH}$ neurons was reduced, and (3) the frequency of spontaneous excitatory postsynaptic currents to PVN neurons was dramatically reduced (Figure 1). The same measures were taken in the thalamus and yielded no changes. Similarly, there were no changes in markers of inhibitory transmission. Together these data strongly support the notion that augmented maternal care reduces excitatory drive to the CRH-expressing neuron in the PVN.

Whereas the correlation between reduction in excitation and reduction of $\mathrm{CRH}$ expression is suggestive, it does not answer the question of causality: is reduced glutamatergic input to a $\mathrm{CRH}$ cell required and sufficient to repress CRH? To address this question, in vitro methods have been initiated, with the use of organotypic hypothalamic slice cultures to isolate the PVN. In this system, application of glutamate receptor antagonists (blocking both AMPA- and NMDA-type receptors) can effectively eliminate ionotropic glutamatergic transmission. Pilot data suggests that this manipulation may suffice to repress CRH mRNA levels compared to vehicle-treated controls (24). These initial findings are consistent with the notion that augmented maternal care reduces excitatory drive to the PVN, which in turn leads to reduced CRH mRNA production.

\section{HOW DOES THE SENSORY SIGNAL FROM MATERNAL CARE REACH THE PVN AND SERVE TO REDUCE EXCITATORY SYNAPSE NUMBER AND FUNCTION?}

Maternal input to her progeny consists of a variety of stimuli, among which sensory stimuli and especially touch (licking,

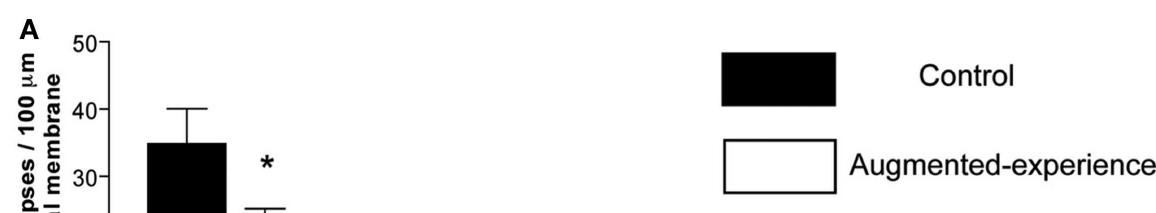

FIGURE 1 | Augmented early-life experience reduces the number and function of excitatory synapses in the paraventricular nucleus of the hypothalamus (PVN). (A) Total number of synapses was reduced by $50 \%$, attributable to a $70 \%$ reduction of asymmetric (excitatory) synapses onto $\mathrm{CRH}$-expressing neurons in the PVN. (B) Levels of the vesicular transporter
vGlut2, a marker of glutamate-containing synaptic vesicles, were reduced by approximately $40 \%$ in rats with augmented early-life experience relative to controls. (C) Miniature excitatory postsynaptic currents (mEPSC) frequency was reduced by $60 \%$ in putative $\mathrm{CRH}$ neurons. Adapted from Ref. (11) with permission from the Journal of Neuroscience. 
grooming) appear to be the most important (25-27). Levine's group demonstrated that augmented HPA responses to stress caused by $24 \mathrm{~h}$ maternal deprivation could be prevented by stroking the pups, highlighting the importance of tactile stimulation to normal development of HPA activity (28). Using brainmapping methods, the pathways through which these signals reach the PVN have been identified (29).

Glutamate-specific retrograde tracing revealed that excitatory afferents terminating in the PVN originate in the paraventricular thalamus (PVT), lateral septum, bed nucleus of the stria terminalis (BNST), and amygdala (30). The BNST integrates and relays signals from the limbic forebrain and amygdala and provides both inhibitory and excitatory drive to the PVN. Specifically, posterior sub-regions inhibit stress-induced CRH expression in the PVN, whereas anterior regions facilitate it (31). The central nucleus of the amygdala (CeA), important for integration of autonomic inputs, facilitates CRH release from the PVN (Figure 2), likely via the BNST $(32,33)$.

Importantly, both the CeA and BNST are activated by maternal care. Handling rat pups evokes a burst of nurturing behavior (licking and grooming) by the dam upon the pups' return to the home cage. A single instance of handling results in c-fos activation in both BNST and CeA (29), yet did not influence CRH expression. In contrast, recurrent handling for a week, which led to repression

\section{A Single day of augmented maternal care}

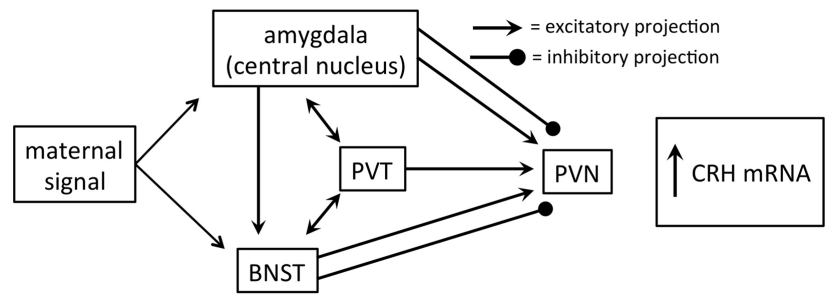

B Recurrent daily barrages of augmented maternal care

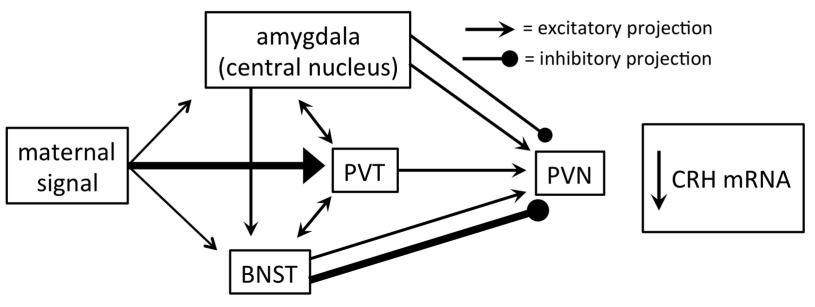

FIGURE 2 | Proposed circuitry involved in conveying maternal-derived sensory input to CRH-expressing neurons in the PVN. The PVN receives excitatory and inhibitory projections, including projections from the amygdala, paraventricular thalamic nucleus (PVT), and bed nucleus of the stria terminalis (BNST). These regions are also interconnected by excitatory projections (solid black lines). (A) The amygdala and BNST are both activated after a single day of handling-evoked augmented maternal care, and in turn stimulate the PVN (29). (B) The PVT is not activated after a single day of augmented maternally derived sensory input, but is recruited by recurrent daily barrages. This is thought to activate regions of the BNST that inhibit CRH-expressing neurons in the PVN (31). It is not fully known how this series of events promotes reduced numbers of excitatory synapses on $\mathrm{CRH}$-expressing neurons. of CRH expression, was associated with c-fos activation also within the PVT (29). This suggests that the contribution of the PVT to the overall circuit that conveys maternal signals to the $\mathrm{CRH}$ cells in the PVN is important to reduce the expression of the gene. The PVT has been shown to play an important role in stress memory and adaptation $(34,35)$. The PVT sends afferents to the PVN, and possesses bidirectional connections with the CeA and BNST (36). Considering that the majority of PVT output to the structures described above are excitatory, how might PVT activation result in repression of the PVN? Here, we speculate that activation of the PVT might excite BNST regions that are known to inhibit $\mathrm{CRH}$ expression in the PVN (Figure 2).

\section{INITIATION VS. MAINTENANCE OF EPIGENETIC REPRESSION OF CRH BY EARLY-LIFE EXPERIENCE}

When considering the changes in gene expression that occur after augmented maternal care, it is important to note two key differences in timing. Repression of CRH begins around postnatal day 9 and persists through adulthood, while changes in glutamatergic signaling to the PVN were noted only at P9 and were back to control levels by P45 (11). This suggests that following the initiation signal mediated by reduction of glutamatergic signaling, there may be additional factors that are involved in maintaining the repression of gene expression that persists long past the initiating signal. Such factors are likely to be epigenetic in nature.

A likely suspect is the neuronal repressor neuron restrictive silencer factor (NRSF). NRSF is a transcription factor that silences gene expression via epigenetic modifications. The CRH intron contains a functional NRSF binding sequence (37), suggesting that the programing of the $c r h$ gene during early postnatal life may be due to NRSF activity. In fact, NRSF levels in the PVN are dramatically upregulated following augmented maternal care, starting at P9 and persisting into adulthood (11). This pattern is an inverse correlate of CRH expression levels following augmented maternal care, supporting the idea that NRSF may be involved in mediating $\mathrm{CRH}$ repression.

\section{IMPLICATIONS FOR PTSD}

Post-traumatic stress disorder is often associated with a history of early-life trauma $(19,38-40)$, and more specifically with chronic stressful situations such as abuse and long-lasting war rather than an acute event (41-47). PTSD is characterized by a persistently dysregulated stress response $(19,48,49)$, and it is reasonable to assume that chronic early-life stressful events influences an individual's stress response to promote PTSD. There are several processes that might account for altered stress responses in PTSD. It has been posited that the hypothalamic-pituitary-adrenal axis is permanently sensitized by chronic early-life abuse, and this creates a vulnerability to subsequent trauma, resulting in PTSD. However, the mechanism of such sensitization is unclear. Here we provide a novel and plausible solution: if chronic early-life predictable and nurturing maternal care can reduce excitatory synaptic input onto stress-sensitive neurons in the hypothalamus, and hence "desensitize" future stress responses, then might abusive, erratic, or neglectful maternal behavior provoke the opposite? Augmentation of excitatory input to hypothalamic CRH cells may well serve to sensitize CRH release to future stresses. Whereas 
this notion is speculative at this point, it is highly amenable to direct testing in animal models. A second possible basis of the abnormal stress response in PTSD that follows early-life chronic stress/abuse may include aberrant regulation of the expression of relevant genes, such as $\mathrm{CRH}$. Here we provide insight into how early-life experience - nurturing or adverse - can result in persistently altered regulation of $\mathrm{CRH}$ expression. The lifelong changes in $\mathrm{CRH}$ release and expression that result from chronic early-life

\section{REFERENCES}

1. Bale TL, Baram TZ, Brown AS, Goldstein JM, Insel TR, McCarthy $\mathrm{MM}$, et al. Early life programming and neurodevelopmental disorders. Biol Psychiatry (2010) 68:314-9. doi:10.1016/j.biopsych.2010.05.028

2. Szyf M. How do environments talk to genes? Nat Neurosci (2013) 16:24. doi:10.1038/nn.3286

3. Krishnan V, Nestler EJ. The molecular neurobiology of depression. Nature (2008) 455:894-902. doi:10. 1038/nature07455

4. Liu D, Diorio J, Tannenbaum B, Caldji C, Francis D, Freedman A, et al. Maternal care, hippocampal glucocorticoid receptors, and hypothalamic-pituitaryadrenal responses to stress. Science (1997) 277:1659-62. doi:10.1126/ science.277.5332.1659

5. Avishai-Eliner S, Eghbal-Ahmadi M, Tabachnik E, Brunson KL, Baram TZ. Down-regulation of hypothalamic corticotropinreleasing hormone messenger ribonucleic acid (mRNA) precedes early-life experience-induced changes in hippocampal glucocorticoid receptor mRNA. Endocrinology (2001) 142:89-97. doi:10.1210/en.142.1.89

6. Chen J, Evans AN, Liu Y, Honda M, Saavedra JM, Aguilera G. Maternal deprivation in rats is associated with corticotrophin-releasing hormone $(\mathrm{CRH})$ promoter hypomethylation and enhances $\mathrm{CRH}$ transcriptional responses to stress in adulthood. J Neuroendocrinol (2012) 24:105564. doi:10.1111/j.1365-2826.2012. 02306.x

7. Ivy AS, Rex CS, Chen Y, Dube C, Maras PM, Grigoriadis DE, et al. Hippocampal dysfunction and cognitive impairments provoked by chronic early-life stress involve excessive activation of CRH receptors. J Neurosci (2010) 30:1300515. doi:10.1523/JNEUROSCI.178410.2010

8. Avishai-Eliner S, Gilles EE, EghbalAhmadi Y, Bar-El Y, Baram TZ. Altered regulation of gene and protein expression of hypothalamicpituitary-adrenal axis components in an immature rat model of chronic stress. I Neuroendocrinol (2001) 13:799-807. doi:10.1046/j. 1365-2826.2001.00698.x

9. Baram TZ, Davis EP, Obenaus A, Sandman CA, Small SL, Solodkin A, et al. Fragmentation and unpredictability of early-life experience in mental disorders. Am J Psychiatry (2012) 169:907-15. doi:10.1176/appi.ajp. 2012.11091347

10. Weaver IC, Cervoni N, Champagne FA, D'Alessio AC, Sharma S, Seckl JR, et al. Epigenetic programming by maternal behavior. Nat Neurosci (2004) 7:847-54.

11. Korosi A, Shanabrough M, McClelland S, Liu ZW, Borok E, Gao $\mathrm{XB}$, et al. Early-life experience reduces excitation to stressresponsive hypothalamic neurons and reprograms the expression of corticotropin-releasing hormone. $J$ Neurosci (2010) 30:703-13. doi:10. 1523/JNEUROSCI.4214-09.2010

12. Murgatroyd C, Patchev AV, Wu Y, Micale V, Bockmuhl Y, Fischer D, et al. Dynamic DNA methylation programs persistent adverse effects of early-life stress. Nat Neurosci (2009) 12:1559-66. doi:10.1038/nn. 2436

13. Plotsky PM, Meaney MJ. Early, postnatal experience alters hypothalamic corticotropin-releasing factor (CRF) mRNA, median eminence CRF content and stress-induced release in adult rats. Brain Res $\mathrm{Mol}$ Brain Res (1993) 18:195-200. doi: 10.1016/0169-328X(93)90189-V

14. Rivier C, Brownstein M, Spiess J, Rivier J, Vale W. In vivo corticotropin-releasing factor-induced secretion of adrenocorticotropin, betaendorphin, and corticosterone. Endocrinology (1982) 110:272-8. doi:10.1210/endo-110-1-272

15. Fenoglio KA, Brunson KL, AvishaiEliner S, Stone BA, Kapadia BJ, Baram TZ. Enduring, handlingevoked enhancement of hippocampal memory function and glucocoractivation of the corticotropinreleasing factor type 1 receptor. Endocrinology (2005) 146:4090-6. doi:10.1210/en.2004-1285 ticoid receptor expression involves

experiences may provide the neurobiological basis for resilience or vulnerability to subsequent stress, and hence to the development of PTSD.

\section{ACKNOWLEDGMENTS}

The excellent editorial assistance of Mrs. Barbara Cartwright is appreciated. Authors' research has been supported by NIH grants NS28912; MH73136 NS 45260 (CM Gall, PI).

16. Bremner JD, Licinio J, Darnell A, Krystal JH, Owens MJ, Southwick SM, et al. Elevated CSF corticotropin-releasing factor concentrations in posttraumatic stress disorder. Am J Psychiatry (1997) 154:624-9.

17. de Kloet CS, Vermetten E, Geuze E, Lentjes EG, Heijnen CJ, Stalla GK, et al. Elevated plasma corticotrophinreleasing hormone levels in veterans with posttraumatic stress disorder. Prog Brain Res (2008) 167:28791. doi:10.1016/S0079-6123(07) 67025-3

18. Bonne O, Gill JM, Luckenbaugh DA, Collins C, Owens MJ, Alesci S, et al. Corticotropin-releasing factor interleukin-6, brain-derived neurotrophic factor, insulin-like growth factor-1, and substance $P$ in the cerebrospinal fluid of civilians with posttraumatic stress disorder before and after treatment with paroxetine. J Clin Psychiatry (2011) 72:1124-8. doi:10.4088/JCP.09m05106blu

19. Pitman RK, Rasmusson AM, Koenen KC, Shin LM, Orr SP, Gilbertson MW, et al. Biological studies of post-traumatic stress disorder. Nat Rev Neurosci (2012) 13:769-87. doi: 10.1038/nrn3339

20. West AE, Griffith EC, Greenberg ME. Regulation of transcription factors by neuronal activity. Nat Rev Neurosci (2002) 3:921-31. doi:10. 1038/nrn987

21. Cole RL, Sawchenko PE. Neurotransmitter regulation of cellular activation and neuropeptide gene expression in the paraventricular nucleus of the hypothalamus. J Neurosci (2002) 22:959-69.

22. Ziegler DR, Herman JP. Local integration of glutamate signaling in the hypothalamic paraventricular region: regulation of glucocorticoid stress responses. Endocrinology (2000) 141:4801-4. doi:10.1210/en. 141.12 .4801

23. Bartanusz V, Muller D, Gaillard RC, Streit P, Vutskits L, Kiss JZ. Local gamma-aminobutyric acid and glutamate circuit control of hypophyseotrophic corticotropinreleasing factor neuron activity in the paraventricular nucleus of the hypothalamus. Eur J Neurosci
(2004) 19:777-82. doi:10.1111/j. 1460-9568.2004.03167.x

24. Cope J, McClelland S, Korosi A, Yang J, Koh A, Baram TZ. Epigenetic mechanisms of life-long hypothalamic CRH repression following augmented maternal care involve NRSF-mediated transcriptional repression and chromatin changes. Abstract \#503.11 Presented at the Annual Meeting of the Society for Neuroscience. Washington, DC (2011).

25. Suchecki D, Nelson DY, Van Oers H, Levine S. Activation and inhibition of the hypothalamic-pituitaryadrenal axis of the neonatal rat: effects of maternal deprivation. Psychoneuroendocrinology (1995) 20:169-82. doi:10.1016/03064530(94)00051-B

26. Eghbal-Ahmadi M, Avishai-Eliner S, Hatalski CG, Baram TZ. Differential regulation of the expression of corticotropin-releasing factor receptor type 2 (CRF2) in hypothalamus and amygdala of the immature rat by sensory input and food intake. J Neurosci (1999) 19:3982-91.

27. Korosi A, Baram TZ. The pathways from mother's love to baby's future. Front Behav Neurosci (2009) 3:27. doi:10.3389/neuro.08.027.2009

28. van Oers HJ, de Kloet ER, Whelan $\mathrm{T}$, Levine S. Maternal deprivation effect on the infant's neural stress markers is reversed by tactile stimulation and feeding but not by suppressing corticosterone. J Neurosci (1998) 18:10171-9.

29. Fenoglio KA, Chen Y, Baram TZ. Neuroplasticity of the hypothalamic-pituitary-adrenal axis early in life requires recurrent recruitment of stressregulating brain regions. $J$ Neurosci (2006) 26:2434-42. doi:10.1523/ JNEUROSCI.4080-05.2006

30. Csaki A, Kocsis K, Halasz B, Kiss J. Localization of glutamatergic/aspartatergic neurons projecting to the hypothalamic paraventricular nucleus studied by retrograde transport of $[3 \mathrm{H}] \mathrm{D}$ aspartate autoradiography. Neuroscience (2000) 101:637-55. doi:10. 1016/S0306-4522(00)00411-5 
31. Choi DC, Furay AR, Evanson NK, Ostrander MM, Ulrich-Lai YM, Herman JP. Bed nucleus of the stria terminalis subregions differentially regulate hypothalamic-pituitaryadrenal axis activity: implications for the integration of limbic inputs. J Neurosci (2007) 27:2025-34. doi:10.1523/JNEUROSCI.4301-06. 2007

32. Prewitt CM, Herman JP. Lesion of the central nucleus of the amygdala decreases basal CRH mRNA expression and stress-induced ACTH release. Ann N Y Acad Sci (1994) 746:438-40. doi:10.1111/j.17496632.1994.tb39279.x

33. Herman JP, Figueiredo H, Mueller NK, Ulrich-Lai Y, Ostrander MM, Choi DC, et al. Central mechanisms of stress integration: hierarchical circuitry controlling hypothalamopituitary-adrenocortical responsiveness. Front Neuroendocrinol (2003) 24:151-80. doi:10.1016/j.yfrne.2003.07.001

34. Bhatnagar S, Huber R, Nowak N, Trotter P. Lesions of the posterior paraventricular thalamus block habituation of hypothalamicpituitary-adrenal responses to repeated restraint. J Neuroendocrinol (2002) 14:403-10. doi:10. 1046/j.0007-1331.2002.00792.x

35. Bhatnagar S, Dallman M. Neuroanatomical basis for facilitation of hypothalamic-pituitaryadrenal responses to a novel stressor after chronic stress. Neuroscience (1998) 84:1025-39. doi:10. 1016/S0306-4522(97)00577-0

36. Van der Werf YD, Witter MP, Groenewegen HJ. The intralaminar and midline nuclei of the thalamus. Anatomical and functional evidence for participation in processes of arousal and awareness. Brain Res Brain Res Rev (2002) 39:107-40. doi:10.1016/S01650173(02)00181-9

37. Seth KA, Majzoub JA. Repressor element silencing transcription factor/neuron-restrictive silencing factor (REST/NRSF) can act as an enhancer as well as a repressor of corticotropin-releasing hormone gene transcription. J Biol Chem (2001) 276:13917-23.

38. Bremner JD, Southwick SM, Johnson DR, Yehuda R, Charney DS. Childhood physical abuse and combat-related posttraumatic stress disorder in Vietnam veterans. Am J Psychiatry (1993) 150:235-9.

39. Lang AJ, Aarons GA, Gearity J, Laffaye C, Satz L, Dresselhaus TR, et al. Direct and indirect links between childhood maltreatment, posttraumatic stress disorder, and women's health. Behav Med (2008) 33:125-35. doi:10.3200/BMED.33. 4.125-136

40. Cougle JR, Timpano KR, SachsEricsson N, Keough ME, Riccardi CJ. Examining the unique relationships between anxiety disorders and childhood physical and sexual abuse in the National Comorbidity Survey-Replication. Psychiatry Res (2010) 177:150-5. doi:10. 1016/j.psychres.2009.03.008

41. Lindberg FH, Distad LJ. Posttraumatic stress disorders in women who experienced childhood incest. Child Abuse Negl (1985) 9:329-34. doi:10.1016/01452134(85)90028-6

42. Rodriguez N, Ryan SW, Vande Kemp H, Foy DW. Posttraumatic stress disorder in adult female survivors of child sexual abuse: a comparison study. J Consult Clin Psycho (1997) 65:53-9. doi:10.1037/0022006X.65.1.53

43. Yehuda R, Schmeidler J, Siever LS Binder-Byrnes K, Elkin A. Individual differences in posttraumatic stress disorder symptom profiles in Holocaust survivors in concentration camps or in hiding. $J$ Trauma Stress (1997) 10:453-63. doi:10. 1023/A:1024860430725

44. Ackerman PT, Newton JE, McPherson WB, Jones JG, Dykman RA. Prevalence of post traumatic stress disorder and other psychiatric diagnoses in three groups of abused children (sexual, physical, and both). Child Abuse Negl (1998) 22:759-74. doi:10.1016/S01452134(98)00062-3

45. McLeer SV, Dixon JF, Henry D, Ruggiero K, Escovitz K, Niedda T, et al. Psychopathology in non-clinically referred sexually abused children. J Am Acad Child Adolesc Psychiatry (1998) 37:1326-33. doi:10.1097/ 00004583-199812000-00017

46. Saigh PA, Bremner JD. The history of post-traumatic stress disorder. In: Saigh PA, Bremner JD editors. Posttraumatic Stress Disorder: A Comprehensive Textbook. Needham Heights, MA: Allyn \& Bacon (1999) p. 1-17.

47. Pratchett LC, Yehuda R. Foundations of posttraumatic stress disorder: does early life trauma lead to adult posttraumatic stress disorder? Dev Psychopathol (2011) 23:477-91. doi:10.1017/ S0954579411000186

48. Yehuda R, Flory JD, Pratchett LC, Buxbaum J, Ising $\mathrm{M}$, Holsboer $\mathrm{F}$.
Putative biological mechanisms for the association between early life adversity and the subsequent development of PTSD. Psychopharmacology (Berl) (2010) 212:405-17. doi: 10.1007/s00213-010-1969-6

49. Zoladz PR, Diamond DM. Current status on behavioral and biological markers of PTSD: a search for clarity in a conflicting literature. Neurosci Biobehav $\operatorname{Rev}(2013)$ 37:860-95. doi:10.1016/ j.neubiorev.2013.03.024

Conflict of Interest Statement: The authors declare that the research was conducted in the absence of any commercial or financial relationships that could be construed as a potential conflict of interest.

Received: 31 May 2013; accepted: 30 July 2013; published online: 15 August 2013. Citation: Karsten CA and Baram TZ (2013) How does a neuron "know" to modulate its epigenetic machinery in response to early-life environment/ experience? Front. Psychiatry 4:89. doi: 10.3389/fpsyt.2013.00089

This article was submitted to Frontiers in Molecular Psychiatry, a specialty of Frontiers in Psychiatry.

Copyright (c) 2013 Karsten and Baram. This is an open-access article distributed under the terms of the Creative Commons Attribution License (CC BY). The use, distribution or reproduction in other forums is permitted, provided the original author(s) or licensor are credited and that the original publication in this journal is cited, in accordance with accepted academic practice. No use, distribution or reproduction is permitted which does not comply with these terms. 